\title{
The Newcomer's Psychological Contract Breach and Its Change
}

\author{
Kyung Min $\mathrm{Kim}^{\dagger}$
}

\author{
Hyoung Koo Moon ${ }^{+\dagger}$
}

Korea University, Business School

This study has two primary aims: (1) to investigate the relationship between how the newcomer perceives employer promises psychological contract breach, and (2) to understand how these rates change over time. A total of 222 newcomers at major Korean companies were surveyed twice at a three-month interval. Results showed that both levels of perceived employer promise and psychological contract breach decreased over time as individuals accumulated real job experience. Also, the change in perceived employer promises was positively related to the change in breach perception. As their perceived employer promise level decreases over time, newcomers perceived fewer psychological contract breaches. This study provides evidence that a newcomer's breach perception could result from overestimation of employer promise and that job experience plays a role in adjusting employer promise perception to an appropriate level, thereby lowering breach perception. These findings suggest that newcomers' breach perception may be different from that of existing employees, due to incomplete initial understanding of employer promise, leading to increased frequency of breach perception. Practitioners may also benefit from education on new approaches for managing newcomers' breach perception.

Key words : Psychological contract breach, employer promise, newcomers; sensemaking

\footnotetext{
† Kyung Min Kim: Corresponding Author, Ph.D. in Management, Korea University Business School soyeon02@korea.ac.kr

†† Hyoung Koo Moon: Professor in Management, Korea University Business School, hkmoon@korea.ac.kr
} 


\section{Introduction}

Psychological contract breach has been found to have a negative influence on a variety of individual work attitudes and behaviors, including job satisfaction(Tekleab \& Taylor, 2003), in-role and extra-role performance(Lester, Turnley, Bloodgood, \& Bolino, 2002; Robinson, 1996; Turnley \& Feldman, 2000), and trust and organizational commitment(Lester et al., 2002; Robinson, 1996). Consequently, previous studies have attempted to identify antecedents of breach perception. For example, it has been suggested that human resources practices(Guest \& Conway, 2000), organizational performance levels(Robinson \& Morrison, 2000), and organizational support (Tekleab, Takeuchi, \& Taylor, 2005) are related to a newcomer's breach perception. However, little attention has been paid to the process of breach perception. Newcomers enter employment with an incomplete understanding of the psychological contract and over time are engaged in the process of forming reciprocal promises (Conway \& Briner, 2005; Rousseau, 1995). Therefore, a newcomer's cognitive mechanism for perceiving a breach may be quite different from that of an existing employee.

This study aims to investigate unique characteristics of newcomer breach perception with a focus on identifying primary causes and change over time. First, the primary cause of breach perception may stem from overestimation of employer promises, rather than insufficient organizational inducements. This overestimation may result from sales communications during the recruitment and selection processes, whereby the organization emphasizes potential future benefits for the individual. Second, newcomers may experience change in promise and breach levels, such that high initial levels of employer promise and breach perceptions decrease over time as individual accumulates job experience. Job experience plays a significant role in adjusting employer promise perception to a more realistic level. Previous studies on contract formation in newcomers simply suggested that this promise level is related to real experience with organizational inducements and individual contributions(De Vos, Buyens, \& Schalk, 2003). The present study clarifies this relationship further, demonstrating that real job experience functions to lower employer promise perception and contributes to the formation of a more complete psychological contract. This study also suggests that newcomers' perceptions for the employer promise could be considered to be a cause of psychological contract breach. These results deepen the understanding of newcomers' breach perceptions by suggesting a specific cognitive mechanism of change, which has rarely been addressed in the previous literature. Important implications for the role of realistic job preview are also identified. Previous studies about realistic recruitment and job preview have not considered the concept of psychological contract, focusing on the factors such as 
newcomers' intention to quit, job satisfaction, and organizational commitment(김영국, 2006; 신수식 \& 신창근, 2001). This study proposes that newcomers' psychological contract breach perception is another factor that can be influenced by the realistic management of early job experiences.

\section{Overestimated employer promises and psychological contract breach}

Cassar, Buttigies, and Briner (2005) recently proposed five causal explanations for psychological contract breach: delay(the fulfillment of the promise occurred later than expected), magnitude(what was delivered was less than what was promised), type/form(what was delivered is different from what was promised), inequity(what they received was less than what others were awarded), and reciprocal imbalance (what they were giving was more than what they were gaining from the organization). For long-term employees of an organization, one of these experiences may precipitate a perceived breach of psychological contract. However, a newcomer's perception of a contract breach may be based on very different factors. Previous research has ignored the unique characteristics of newcomers' breach perception; consequently, it remains unclear how to best prevent newcomers from becoming dissatisfied with an organization or from forming an intention to quit based upon a perceived breach of their psychological contract.

One the few studies focusing on newcomers' psychological contract perceptions proposed that a gradual model of development, whereby employer and employee promise expectations are slowly shaped through experience of real inducements and contributions on the job De Vos et al., (2003). Conversely, we propose that newcomers will initially overestimate employer promises and subsequently adjust these expectations to a more realistic level through work experience. The overestimation of employer promises may primarily result from two factors: information content and cognitive strategy. Overestimation may result from information provided to the individual during the course of joining a company. When recruiting and selecting human talent, organizations generally emphasize strengths(Boswell, Boudreau, \& Tichy, 2005; Wanous, 1980). Organizations naturally highlight the various future benefits available to prospective employees and focus communication on the positive rather than negative aspects of the organization(Boswell, Shipp, Payne, \& Culbertson, 2009; Meglino \& DeNisi, 1987; Porter, Lawler, \& Hackman, 1975; Van Maanen, 1975). While this approach stems from an organization's desire to secure top talent through its selection process(Milkovich \& Boudreau, 1997), it leads newcomers to build quite high expectations of future benefits(Boswell et al., 2005; Krausz \& Fox, 1981; Meglino \& DeNisi, 1987). 
It is important to note that this information is not simply interpreted as an expectation, but may be interpreted as a concrete future promise that is accompanied by mutual obligations. This interpretation may be influenced by the newcomer's cognitive strategies, especially sensemaking, uncertainty reduction, and the rationalization of post-decision dissonance. Sensemaking is defined as the process of making meaning of a new situation or experience through subjective interpretation(Saks \& Ashforth, 1997). As a part of this justification process, an individual seeks information to explain an unanticipated situation and make it acceptable (Ring \& Rands, 1989). Sensemaking is not a simple passive interpretation, but rather an active cognitive process, whereby the individual's internal motivations or prior knowledge and experience are actively projected(Weick, 1995).

Through the sensemaking process, positive information about the organization provided during the recruitment and selection processes may be interpreted as future employer promises. The psychological contract consists of both explicit and implicit promises. Whereas explicit promises are stipulated by objective communications (i.e., employment contracts, general regulations and organizational guidelines), implicit promises are formed subjectively, through highly individual psychological processes, and by means of a variety of sources (i.e., interpretation of past events or history, observation of others, vicarious learning and
inference)(Morrison \& Robinson, 1997). Therefore, implicit promises could be inferred through emphasis on organizational intention and the provision of both abstract and general information, including organizational history, mission and vision, $\mathrm{HR}$ principles, strategic goals, performance, and people. For example, a newcomer is informed that the organization previously promoted an employee who applied a creative idea to his or her work. The newcomer could infer an organizational intention of rewarding creativity or encouraging employee suggestions in the workplace. The newcomer then comes to believe that the organization will perform these actions again in the future and may ultimately form an employer promise based upon this belief.

Sensemaking leading to increased promise perception is further facilitated by a newcomer's motivations, most commonly uncertainty reduction and the rationalization of post-decision dissonance. According to uncertainty reduction theory(Falcione \& Wilson, 1988; Lester, 1987), newcomers experience a strong sense of uncertainty about a new organization and the future because they lack a frame of reference and specific knowledge of an organization. The newcomer is then left with a strong desire to resolve this uncertainty. One option for resolution is to specify what an organization will provide a newcomer and what a newcomer expects to do for an organization in reciprocity (future promises). In other words, forming a 
psychological contract is a means of reducing uncertainty; thereby, a newcomer is more likely to attribute future promises or obligations to organizational messages or information.

Post-decision dissonance and rationalization motivations also influence the sensemaking process(Lawler, Kuleck, Rhode, \& Sorenson, 1975; Vroom \& Deci, 1971). A newcomer has already decided to join an organization, which may be considered an important life decision. A wrong employment decision could cause significant damage to a newcomer. A newcomer is therefore likely to perceive a new organization more favorably, especially in terms of understanding what the organization will provide in the future, effectively justifying his or her decision. Even if a newcomer encounters unfavorable aspects of a new organization, he or she is likely to ignore them and concentrate on the favorable aspects that confirm his or her decision(Ashforth, 2001). The resulting effect accords with Rousseau's suggestion that the type of career aspirations an individual has could affect the type of psychological contract he/she makes, because motives filter the information that an individual receives(Rousseau, 1995).

Based upon the combination of positive information provided by the organization during the entry process and internal employee motivations, newcomers are likely to perceive elevated levels of employer promise during the first several months after entry. This overestimation may be regarded as a phenomenon similar to the honeymoon effect, in which a newcomer's job satisfaction level reaches a peak immediately following entry into an organization(Boswell et al., 2005; Boswell, Shipp, Payne, \& Culbertson, 2009). Although unrealistic expectations held by the newcomer serve as the primary influence on initial employer promise perception, early belief structure is later modified by a newcomer's actual job experience in the workplace. The resulting interaction, between action and belief, is central in the sensemaking process. Belief and action mutually influence one another and continue to develop by either reinforcing or negating existing cognitive schema (Weick, 1995). In this process, a weaker side will be revised to match a stronger side. When a belief is strong, a resulting action will be interpreted within the framework of a belief. On the contrary, when an action or experience is stronger than a belief, an individual may change the frame constructed by a belief(Weick, 1995).

Likewise, an early and highly optimistic belief regarding employer promise will be adjusted as a newcomer accumulates workplace experience and job knowledge. During this adjustment process, a newcomer will experience elevated breach perception because his or her initial employer promise perception was too high and therefore very difficult for an organization to fulfill. This stage is comparable to a hangover effect, which follows the honeymoon effect, in that a newcomer effect, which follows the honeymoon effect, decreases as a function of time since entry 
into an organization(Boswell, 2005; Boswell et al, 2009). However, as a newcomer moves through this process he or she begins to more realistically adjust employer promise perception levels; consequently, the level of perceived employer promise is likely to decrease over time. Realistic employer promises are more likely to be fulfilled by an organization, thus the breach level experienced by a newcomer will also decrease as time passes. We posit the following hypotheses based upon this rationale.

Hypothesis 1. The level of newcomers' perceptions of employer promises will decrease over time.

Hypothesis 2. The level of newcomers' breach perceptions of psychological contract will decrease over time.

Hypothesis 3. The change of newcomers' breach perceptions of psychological contract will be positively related to the change of their perceptions of employer promises, regardless of the change of real inducement from the organization.

\section{Method}

\section{Participants and Procedure}

Newcomers to large Korean big companies were invited to participate in surveys. All of the participants had completed orientation programs.
The surveys were conducted twice, separated by a three-month interval. The first survey was conducted when the participants had been working for approximately three months (T1). The second survey was administered to the same participants three months later (T2). This time setting is based on the socialization literature. The speed of socialization does not appear to have a fixed timeframe and various depending on the socialization content(Saks \& Ashforth, 1997). Above all, the perceived future promise of a psychological contract is fundamentally based on role definition or task domain knowledge. According to Ashforth and Saks (1995), personal and role change measured at 4 months predicts the change at 10 months. In addition, Ostroff and Kozlowksi (1992) have suggested that the newcomer's knowledge level in the task domain is highest at 5 months. Therefore, we predicted that the newcomer's promise perception would be stable after 6 months on the job, but that during this period, the individuals would experience changes in their perception. Therefore, we performed the first survey at 3 months and the second at 6 months to capture these changes.

All questionnaires were sent by mail to the participants along with a pre-stamped return envelope. The participants were asked to include their 'personal ID' which comprised a series of letters or numbers, to anonymously match the results of the first and second questionnaires for each person. The total number of participants 
was 241. Among these, 19 cases were excluded due to unfinished questionnaires or unreliable responses, and 222 cases were used as the final data set.

The demographic characteristics of the sample were as follows. The represented industries were service (55 percent), manufacturing (21 percent), high-tech and communication (14 percent), and distribution and other (10 percent). Members of the sample performed the following functions: administrative (40 percent), sales (38 percent), technical (11 percent), R \& D (6 percent), and service (5 percent). A majority of the sample (88 percent) had a four-year college degree, and the rest had a master's degree. A total of 68 percent were male, and the mean age of the sample was 27 years (Standard Deviation: 2.1 years). All of the participants began at an entry-level position with a permanent employment contract. A total of 86 percent of the responders did not have previous job experience under permanent employment.

\section{Measures}

Perceived employer promises were measured by 6 items based on Taylor and Tekleab (2003) and De Vos et al. (2003). Each item represents the extent to which the organization has an obligation to the individual. A sample item is "To what extent has the company promised to provide you with a relatively secure job?". For the content dimension, perceived employer promises cover six areas: job content, fair treatment, social atmosphere, attractive benefits, training, and job security. The items used a 5-point Likert scale ranging from 'not at all' to 'to a very great extent'.

The perceived breach of psychological contract was measured using three items based on the work of Taylor and Tekleab (2003). A sample item is "The company has done a good job of meeting its obligations to me" (reversed item). The extent to which an individual perceives a breach of the organization was marked by a 5-point Likert scale from 'not at all' to 'to a very great extent'.

\section{Results}

All scales showed sufficient to high reliabilities (Cronbach's a: T1 employer promise (0.71), T2 employer promise (0.73), T1 perceived breach (0.79), T2 perceived breach (0.80)). For the validity test, confirmative factor analysis (CFA) for the main variables was used. We estimated two-factor model to ensure that employer promise and psychological contract breach were distinct constructs. It was tested using maximum-likelihood estimation method. As a result, the two-factor model was valid showing acceptable fit indexes $\left(\chi^{2}(115)=32.9, p<.001\right)$. Comparative fit index (CFI), Tucker and Luwis index (TLI), and root-mean square error of approximation (RMSEA) were acceptable (CFI=.967, 
TLI =.922, RMSEA = .044) utilizing commonly accepted cutoff criteria (CFI $>.90$, TLI $>.90$, and RMSEA < .05 by Browne \& Cudeck, 1993; Hu \& Bentler, 1999; Tucker \& Lewis, 1973). All the loadings on the two factors were significant $(p<.001)$ supporting two-factor model.

\section{Hypothesis Testing}

Hypothesis 1 was that perceived employer promise would decrease over time. Paired t-test was conducted to compare the effect of time on the perception of employer promise. The mean of perceived employer promise was 4.19 at T1, and decreased to 4.09 at T2.

The mean difference between the two time points was statistically significant at the specified .01 level, $t(217)=-2.85, p=.005, d=-.10,95 \%$, CI[-.16,-.03]. Therefore, the hypothesis was supported, and perceived employer promise

Table 1. Correlations

\begin{tabular}{|c|c|c|c|c|c|c|c|c|c|c|c|}
\hline & Variable & 1 & 2 & 3 & 4 & 5 & 6 & 7 & 8 & Mean & $\begin{array}{l}\text { Standard } \\
\text { deviation }\end{array}$ \\
\hline 1 & T1 Employer Promises & & & & & & & & & 4.19 & .42 \\
\hline 2 & T1 Perceived Breach & $.56 * *$ & & & & & & & & 2.34 & .70 \\
\hline 3 & T2 Employer Promises & $.60 * *$ & $.28 * *$ & & & & & & & 4.09 & .49 \\
\hline 4 & T2 Perceived Breach & $.22 * *$ & $.41 * *$ & $.29 * *$ & & & & & & 2.22 & .66 \\
\hline 5 & Gender & -.05 & .04 & .04 & .02 & & & & & 1.31 & .46 \\
\hline 6 & Job Category & -.05 & -.06 & -.03 & .06 & .08 & & & & 2.10 & 1.34 \\
\hline 7 & Age & .07 & -.01 & .03 & -.10 & $-.23 * *$ & .01 & & & 2.19 & .40 \\
\hline 8 & Socialization Period & .09 & $.17 * *$ & .09 & -.00 & -.12 & .02 & .01 & & 3.07 & 1.20 \\
\hline
\end{tabular}

Table 2. Paired t-test Results for the Change in Perceived Employer Promise

\begin{tabular}{|c|c|c|c|c|c|c|c|c|}
\hline \multirow{2}{*}{$\begin{array}{l}\text { Dependent } \\
\text { Variable }\end{array}$} & \multirow[t]{2}{*}{ Type } & \multirow[t]{2}{*}{ Mean } & \multirow[t]{2}{*}{$t$} & \multirow[t]{2}{*}{$d f$} & \multirow{2}{*}{$\begin{array}{c}\text { Sig. } \\
\text { (2-tailed) }\end{array}$} & \multirow{2}{*}{$\begin{array}{c}\text { Mean } \\
\text { Difference }\end{array}$} & \multicolumn{2}{|c|}{$\begin{array}{l}95 \% \text { Confidence Interval } \\
\text { of the Difference }\end{array}$} \\
\hline & & & & & & & Lower & Upper \\
\hline Perceived & $\mathrm{T} 1$ & 4.19 & \multirow{3}{*}{$-2.85 * *$} & \multirow{3}{*}{217} & \multirow{3}{*}{.005} & \multirow{3}{*}{-.10} & \multirow{3}{*}{-.16} & \multirow{3}{*}{-.03} \\
\hline Employer & & & & & & & & \\
\hline Promise & $\mathrm{T} 2$ & 4.09 & & & & & & \\
\hline
\end{tabular}

$*_{p}<.05 * * p<.01$ 
Table 3. Means for Employer Promise Sub-Dimensions

\begin{tabular}{ccccc}
\hline No & Dimension & Mean at T1 & Mean at T2 & Difference \\
\hline 1 & Job content & 4.18 & 4.10 & 0.09 \\
\hline 2 & Fair treatment & 4.48 & 4.41 & 0.08 \\
\hline 3 & Social atmosphere & 3.86 & 3.76 & 0.09 \\
\hline 4 & Attractive benefit & 4.19 & 4.08 & 0.10 \\
\hline 5 & Training & 4.30 & 4.17 & 0.14 \\
\hline 6 & Job security & 4.14 & 4.05 & 0.09 \\
\hline
\end{tabular}

decreased as time passed. Specifically, changes in the mean of each sub-dimension are presented at Table 3. Among these sub-dimensions, the most strongly perceived employer promise was fairness, and training showed the greatest decrease, from 4.30 to 4.17 .

Hypothesis 2 was that the perceived breach would decrease over time. Paired t-test was conducted to compare the effect of time on the perception of the breach. As a result, the mean of the perceived breach was 2.34 at $\mathrm{T} 1$, and decreased to 2.22 at T2. This difference was statistically significant, showing that the mean difference between $\mathrm{T} 1$ and $\mathrm{T} 2$ was significant at the specified .01 level, $t(219)=-2.68, p=.008$, $d=-.12,95 \%, \quad$ CI[-.20, -.03]. Therefore, the hypothesis was supported, and the newcomer's perceived breach decreased as time passed.

Hypothesis 3 states that the change in perceived employer promises is positively related to the change in perceived breach over time. To test this hypothesis, a hierarchical regression analysis was used. The independent variable was the change in perceived employer promises between two time points (employer promise at $\mathrm{T} 2$ - employer promise at T1). Likewise, the dependent variable was the change in the perceived breach during this time. We controlled the change in perceived organizational inducements between T1 and T2. Previous

Table 4. Paired t-test Results for the Change in Perceived Breach of Psychological Contract

\begin{tabular}{|c|c|c|c|c|c|c|c|c|}
\hline \multirow{2}{*}{$\begin{array}{l}\text { Dependent } \\
\text { Variable }\end{array}$} & \multirow[t]{2}{*}{ Type } & \multirow{2}{*}{ Mean } & \multirow{2}{*}{$t$} & \multirow{2}{*}{$d f$} & \multirow{2}{*}{$\begin{array}{c}\text { Sig. } \\
\text { (2-tailed) }\end{array}$} & \multirow{2}{*}{$\begin{array}{c}\text { Mean } \\
\text { Difference }\end{array}$} & \multicolumn{2}{|c|}{$\begin{array}{l}95 \% \text { Confidence Interval } \\
\text { of the Difference }\end{array}$} \\
\hline & & & & & & & Lower & Upper \\
\hline \multirow{2}{*}{$\begin{array}{l}\text { Perceived } \\
\text { Breach }\end{array}$} & $\mathrm{T} 1$ & 2.34 & \multirow{2}{*}{$-2.68 * *$} & \multirow{2}{*}{219} & \multirow{2}{*}{.008} & \multirow{2}{*}{-.12} & \multirow{2}{*}{-.20} & \multirow{2}{*}{-.03} \\
\hline & $\mathrm{T} 2$ & 2.22 & & & & & & \\
\hline
\end{tabular}

$* p<.05 * * p<.01$ 
Table 5. Model Summary for the Effect of Change in Perceived Employer Promise on the Change in Perceived Breach of Psychological Contract

\begin{tabular}{|c|c|c|c|c|c|}
\hline \multirow{3}{*}{ Variable } & \multicolumn{5}{|c|}{ Dependent Variable: Change in Perceived Breach } \\
\hline & \multirow{2}{*}{$\begin{array}{c}\text { Model } 1 \\
\beta\end{array}$} & \multicolumn{2}{|c|}{ Model 2} & \multicolumn{2}{|c|}{ Model 3} \\
\hline & & $\beta$ & $p$ & $\beta$ & $p$ \\
\hline Constant & .55 & -.05 & .86 & .08 & .76 \\
\hline Gender & -.10 & .09 & .32 & .02 & .73 \\
\hline Job Category & $.07 *$ & .02 & .49 & .02 & .44 \\
\hline Age & -.16 & -.06 & .55 & -.04 & .58 \\
\hline Socialization Period & $-.09 *$ & -.00 & .96 & -.01 & .87 \\
\hline Change in Perceived Inducement & & $-.89 * *$ & .00 & $-.90 * *$ & .00 \\
\hline Change in Perceived Employer Promise & & & & $.66 * *$ & .00 \\
\hline$R^{2}$ & .05 & & & & \\
\hline$F$ & 2.75 & & & & \\
\hline$\Delta R^{2}$ & & & & & \\
\hline$\Delta F$ & & & & & \\
\hline
\end{tabular}

$\mathrm{N}=222 . * p<.05 * * p<.01$

Model 2: Predictors: (Constant), Control variables, Change in Perceived Inducement

Model 3: Predictors: (Constant), Control variables, Change in Perceived Inducement, Change in Perceived Employer Promise

literature suggests that the inducement level has a significant effect on the breach perception (Montes \& Zweig, 2009). Because the present study focused on the unique role of promise in perceiving a psychological contract breach beyond that accounted for by perceived inducements, we controlled the change in inducement perceived by newcomers. In addition, demographic variables such as gender, age, job category, and socialization period, which might have an effect on breach perception, were controlled in the regression analysis.
Consequently, the change in perceived employer promises explained a unique variance for the change in perceived breach, $R^{2}=.50, \triangle$ $R^{2}=.14, F(1,210)=35.08, p=.00$. The regression weight of the change in perceived employer promises was $\beta=.66(p=.000)$, implying that the two variables are positively related. As expected, the change in perceived inducement level (inducement at $\mathrm{T} 2$ - inducement at $\mathrm{T} 1$ ) also explained significant variance for the change in breach $(\beta=-.90, p=.00)$. However, regardless of the inducement level, the change in perceived 
employer promises explained unique variance in the change of breach perceptions. Therefore, the hypothesis was supported, and the change in perceived employer promises was positively related with the change in perceived breach, such that newcomers perceived less of a breach of psychological contract as their perceived employer promise level decreased over time.

\section{Discussion}

The results of this study suggest that newcomers have an high perception of employer promises, which is related to the high level of breach perception during initial stages of employment. As time passes, however, employer promise perception is adjusted to a lower level, resulting in decreased breach perception over time. These results have several important theoretical implications

First, the present results imply that a psychological contract breach could result from the perception of employer promises, regardless of actual organization inducement. These results are contrary to Montes and Zweigs's suggestion that if the inducement level is low, employees may perceive a breach of psychological contract, even in the absence of employer promises. Based upon this proposal, the authors insisted that the promise itself has little impact on a psychological contract breach(Montes \& Zweig, 2009). Conversely, the present study suggests that regardless of the inducement level, newcomers perceive a psychological contract breach congruent to the perceived level of employer promise. These findings indicate that promise perception is an important factor in breach perception; therefore, promise remains the core element of the psychological contract breach.

Newcomers' high expectations regarding employer promise, which are formed through inducement-friendly information presented during the selection process, could explain this result. However, when this result is applied to existing employees, this finding could instead result from a disagreement in implicit promises between an individual and an organization. According to schema theory, promise in a psychological contract could be seen as a type of "event schema," which is an individual's knowledge set concerning social contexts, events, or situations (i.e., a personal scenario, such as an event, will unfold in a certain way). A psychological contract is a mental model, so implicit promises differ between employees and an organization, as well as between individuals. When there is a discrepancy between an individual's and organization's perceptions of employer promises, an individual is more likely to perceive a breach, regardless of the actual inducements provided.

Considering this perspective, several additional factors could theoretically be considered antecedents of contract breach. For example, person-organization fit (P-O fit), defined as the 
level of congruence in value schema between an individual and an organization, may influence breach perception. P-O fit may reflect the extent to which an individual and an organization agree on implicit promises and thus be related to perceived breaches of psychological contract. Therefore, future research on psychological contract breach must focus more closely on individual research on domains, including specifics of implicit promises, the correspondence of promise content with the organization, and the balance between employer and employee promises.

The formation of a psychological contract is also developed through an adjustment process, in which high initial expectations of employer promises decreases over time. Previous studies on contract formation have overlooked specific changes in promise level that occur during this formative period. The present study suggests that a newcomer's experiences change his or her promise and breach perception levels, during early stages of employment. Theoretically, it is particularly meaningful that employer promise perception levels decreased naturally over time with job experience. Although previous research has suggested that a newcomer's perceived promise level may change according to his or her perception of inducements and/or contributions(De Vos et al., 2003), the mechanism by which perception of promise generally shifts during formation has remained unclear. The present study suggests a predictable pattern of change in promise level and emphasizes the newly identified role of real job experience in shaping psychological contract formation; over time, perceived employer promise self-corrects to a more realistic level and contributes to the formation of a more complete psychological contract.

Newcomers who exhibit high levels of perceived employer promise upon joining a company provide important implications on the process of promise development. High promise levels may be fostered by the organization's sales communications, which excessively emphasize future inducements. However, high promise levels may also have important implications for the cognitive resources that newcomers use to mentally form future promises. Newcomers may perceive employer promises from explicit communications with an organization, as well as more general messages from an organization. General information about an organization may be an important resource for anticipating employer promises, because these messages contain important cues for organizational intentions(Rousseau, 1995). Employer promises may be formed through exposure to these organizational intention cues, leading newcomers to develop a belief that an organization will perform certain actions in the future. The resulting belief then becomes a basis for future promises. In this respect, a high promise level during the early stages of the job empirically supports a newcomer's implicit formation 
mechanism of future promises.

Finally, these results provide implications for organizational socialization research. The socialization outcomes analyzed in previous studies focused on variables, such as organizational commitment, job satisfaction, and job performance(Adkins, 1995; Ashforth \& Saks, 1997; Major, Kozlowski, Chao, \& Gardner, 1995; Morrison, 1993). However, if a newcomer's promise formation is considered to be part of socialization(Rousseau, 1995) and the newcomer's perception of breach can be considerably explained by perceived employer promises, then a breach of psychological contract should be considered an outcome of organizational socialization. Furthermore, these findings suggest that psychological contract breach is distinct from other socialization outcomes, in that the perception of breach should develop through an unstable adjustment process. Although a high level of breach in the early stages could be interpreted similarly to expected decreases in employee motivation and attitudes following job entry (hangover effect) (Boswell et al., 2005, Hom \& Griffeth, 1991; Lawler et al., 1975; Van Maanen, 1975), breach levels demonstrated a second decrease at approximately 6 months after entry. This decrease pattern conflicts with the previously held view that outcomes of socialization processes are highly stable during the first several months on a job(Adkins, 1995; Morrision, 1993).

Considering these theoretical implications, this study seeks to provide practical implications for organizations. First, newcomer's overestimate employer promises based upon information provided during the selection or socialization processes. Therefore, during the recruiting and training stages, an organization should appropriately manage information to prevent newcomer over-evaluation of the organization's intentions with respect to future inducements. Although initial perception is later adjusted to more realistic levels through work experience, newcomers may experience a strong sense of breach during the early stages of employment. In the event that this process is not adequately controlled, the newcomer may experience a wide range of resulting negative attitudes and emotions(Lester et al, 2002; Robinson, 1996; Turnley \& Feldman, 2000). From this perspective, realistic recruitment (i.e., a realistic job preview) is worth consideration as one means of effectively managing psychological contract development (Meglino, DeNisi, \& Youngblood, 1988; Rousseau, 1995). Among perceived employer promise dimensions, training showed the largest decrease over time. This result can be interpreted to mean that training is the most over-estimated employer promise. Therefore, organizations must be careful in communications about training.

Attending to the role of job experience in lowering promise and breach levels, organizations must design the newcomer's job scope such that 
he/she is able to appropriately and quickly adjust these levels. From a leadership perspective, frontline managers and HR managers should be aware of this effect and make adjustments for a newcomer accordingly because the level of an individual job is determined by a combination of job design and a supervisor's capacity. Guest and Conway have suggested that the rhetoric of middle managers may exaggerate an individual's perception of HR systems quality(Guest \& Conway, 2000); therefore, a supervisor's leadership style should be carefully geared toward settling promise and breach perception levels.

The present study has several limitations. First, it only focuses on the relationship between promise perception and breach with respect to newcomers. However, the newcomer's psychological contract has various unique features. For example, the implicit promises perceived by a newcomer are different from those of an existing employee in areas such as: degree of detail, belief intensity, and level of continuity. These differences may provide more evidence for determining whether initially perceived promises should be considered a complete psychological contract rather than a part of the "learning process." Therefore, future studies should focus on simultaneous observation of these factors to develop a more complete understanding of the process of psychological contract formation and breach perception.

The scope of this study is also limited to an individual's psychological contracts. In principle, the concept of psychological contracts is based on the perceptions of both an organization and an individual(Conway \& Briner, 2005). Consequently, future studies must approach study of the breach of psychological contracts from the perspectives of both employer and employee. Topics for continued study might also include the degree of alignment between the content of promises perceived by an organization and the content perceived by and individual. In addition, how accurately an organization's intentions are delivered to an individual and construed as promises, will serve as important factors in understanding and managing the psychological contract. More specifically, because a newcomer is not fully socialized at entry, his or her methods or sources of breach perception may differ from those of existing employees. Therefore, to enhance our understanding of the process of psychological contract breach, future studies must be conducted from a qualitative perspective.

\section{References}

김영국 (2006). 신입사원 채용과정에서 현실적 직무사전소개의 영향. 외식경영연구, 9(1), 91-108.

신수식 \& 신창근 (2001). 신입사원에 대한 현

실적 직무 소개가 입사 후 직무태도에 미 치는 영향에 관한 연구. 조직과 인사관리 
연구, 25(2), 375-404.

Adkins, C. L. (1995). Previous work experience and organizational socialization: A longitudinal examination. Academy of Management Journal, 38(3), 839-862.

Ashforth, B. E. (2001). Role transitions in organizational life: An identity-based perspective. Mahwah, NJ: Erlbaum.

Ashforth, B. E., \& Saks, A. M. (1995). Work-role transitions: A longitudinal examination of the Nicholson model. Journal of Occupational and Organizational Psychology, 68(2), 157-175.

Ashforth, B. E., \& Saks, A. M. (1997). Organizational Socialization: Making Sense of the Past and Present as a Prologue for the Future. Journal of Vocational Behavior, 51(2), 234-279.

Boswell, W. R., Boudreau, J. W., \& Tichy, J. (2005). The relationship between employee job change and job satisfaction: The honeymoonhangover effect. Journal of Applied Psychology, 90(5), 882-892.

Boswell, W. R., Shipp, A. J., Payne, S. C., \& Culbertson, S. S. (2009). Changes in newcomer job satisfaction over time: Examining the pattern of honeymoons and hangovers. Journal of Applied Psychology, 94(4), 844-858.

Brislin, R. W. (1986). The wording and translation of research instruments. In W. J. Lonner \& J. W. Berry (Eds.), Field methods in crosscultural research (pp. 137-164). Newbury Park, CA: Sage.

Cassar, V., Buttigies, S. C., \& Briner, R. B. (2005). Causal explanations of psychological contract breach characteristics. The Psychologist-

Manager Journal, 16(2), 85-106.

Conway, N. \& Briner, R. (2005). A daily diary study of affective responses to psychological contract breach and exceeded promises. Journal of Organizational Behavior, 23(3), 287- 302.

De Vos, A., Buyens, D., \& Schalk, R. (2003). Psychological contract development during organizational socialization: Adaptation to reality and the role of reciprocity. Journal of Organizational Behavior, 24(5), 537-559.

Falcione, R. L., \& Wilson, C. E. (1988). Socialization processes in organizations. In G. M. Goldhaber \& G. A. Barnett (Eds.), Handbook of organizational communication (pp. 151169). Norwood, NJ: Ablex.

Gioia, D. A. \& Manz, C. C. 1985. Linking cognition and behavior: A script processing interpretation of vicarious learning. Academy of Management Review, 10(3), 527-539.

Gorsuch, Richard L. (1983) Factor Analysis. Hillsdale, NJ: Erlbaum.

Guest, D. \& Conway, N. (2000). The public sector and the psychological contract. IPD Research Report. London: IPD.

Hom, P. W., \& Griffeth, R. W. (1991). Structural equations modeling test of a turnover theory: Cross-sectional and longitudinal analyses. Journal of Applied Psychology, 76(3), 350-366.

Krausz, M., \& Fox, S. (1981). Two dimensions of realistic previews and their impact upon initial expectations, expectation fulfillment, satisfaction, and intention to quit. Journal of Occupational Behavior, 2(3), 211-216.

Lester, R. E. (1987). Organizational culture, 
uncertainty reduction, and the socialization of new organizational members. In S. Thomas (Ed.), Culture and communication: Methodology, behavior, artifacts, and institutions (pp. 105-113). Norwood, NJ: Ablex.

Lawler, E. E., Kuleck, W. J., Rhode, J. G., \& Sorenson, J. E. (1975). Job choice and post decision dissonance. Organizational Behavior \& Human Performance, 13(1), 133-145.

Lester, S. W., Turnley, W. H., Bloodgood, J. M., \& Bolino, M. C. (2002). Not seeing eye to eye: Differences in supervisor and subordinate perceptions of and attributions for psychological contract breach. Journal of Organizational Behavior, 23(1), 39-56.

Major, D. A., Kozlowski, S. W. J., Chao, G. T., \& Gardner, P. D. (1995). A longitudinal investigation of newcomer expectations, early socialization outcomes, and the moderating effects of role development factors. Journal of Applied Psychology, 803), 418-431.

Meglino, B. M., \& DeNisi, A. S. (1987). Realistic job previews: Some thoughts on their more effective use in managing the flow of human resources. Human Resource Planning, 103), 157167.

Meglino, B. M., DeNisi, A. S., \& Youngblood, S. A. (1988). Effects of realistic job preview: A comparison using and enhancement and a reduction preview. Journal of Applied Psychology, 73(2), 259-266.

Milkovich, G. T. \& Boudreau, J. W. (1997). Personnel/human resource management: A diagnostic approach. Homewood, IL: Richard Irwin, Inc. Morrison, E. W. \& Robinson, S. L. (1997). When employees feel betrayed: A model of how psychological contract violation develops. Academy of Management Review, 22(1), 226-256.

Morrison, E. (1993). A longitudinal study of the effects of information seeking on newcomer socialization. Journal of Applied Psychology, 78(2), 173-183.

Montes, S. D., \& Zweig, D. (2009). Do promise matter? An exploration of the role of promise in psychological contract breach. Journal of Applied Psychology, 94(5), 1243-1260.

Ostroff, C., \& Kozlowksi, S. W. J. (1992). Organizational socialization as a learning process: The role of information acquisition. Personnel Psychology, 45(4), 849-874.

Porter, L. W., Lawler, E. E., \& Hackman, J. R. (1975). Behavior in organizations. New York: McGraw-Hill.

Ring, P. S. \& Rands, G. P. (1989). Sensemaking, understanding, and committing: Emergent interpersonal transaction processes in the evolution of 3 M's microgravity research program. In $\mathrm{A} . \mathrm{H}$. Van de Ven, H. L., Angle and M. S. Poole (Eds.), Research on the management of innovation: The Minnesota studies (pp. 337-366). New York: Ballinger.

Robinson, S. L. (1996). Trust and breach of the psychological contract. Administrative Science Quarterly, 41(4), 574-599.

Robinson, S. L. \& Morrison, E. W. (2000). The development of psychological contract breach and violation: A longitudinal study. Journal of Organizational Behavior, 21(5), 525-546.

Rousseau, D. M. (1995). Psychological contracts in organizations: Understanding written and unwritten 
agreement. Sage Publications.

Saks, A. M. \& Ashforth, B. E. (1997) Organizational socialization: Making sense of the past and present as a prologue for the future. Journal of Vocational Behavior, 51(2), 234- 279.

Taylor, S. M. \& Tekleab, A. G. (2003). Aren't there two parties in an employment relationship? Antecedents and consequences of organization-employee agreement on contract obligations and violations. Journal of Organizational Behavior, 24(5), 585-608.

Tekleab, A. G., \& Taylor, M. S. (2003). Aren't there two parties in an employment relationship? Antecedents and consequences of organizational-employee agreement on contract obligations and violations. Journal of Organizational Behavior, 24(5), 585-608.

Turnley, W. H. \& Feldman, D. C. (2000). Re-examining the effects of psychological contract violations: Unmet expectations and job dissatisfaction as mediators. Journal of Organizational Behavior, 21(1), 25-42.
Tekleab, A. G., Takeuchi, R., \& Taylor, M. S (2005). Extending the chain of relationships among organizational justice, social exchange, and employee reactions: The role of contract violations. Academy of Management Journal, 48(1), 146-157.

Van Maanen, J. (1975). Police Socialisation: a longitudinal examination of job attitudes in an urban police department. Administrative Science Quarterly, 20(2), 207-228.

Vroom, V. H., \& Deci, E. L. (1971). The stability of post-decision dissonance: A follow-up study of the job attitudes of business school graduates. Organizational Behavior \& Human Performance, Q(1), 36-49.

Wanous, J. P. (1980). Organizational entry: Recruitment, selection, orientation and socialization of newcomers. Reading, MA: Addison-Wesley.

Weick, K. E. (1995). Sensemaking in Organizations Sage Publications, Inc.

1차 원고접수 : 2015. 07. 14 2차 원고접수 : 2015. 10. 07 최종게재결정 : 2015. 10. 19 
한국심리학회지: 산업 및 조직

Korean Journal of Industrial and Organizational Psychology

2015. Vol. 28, No. 4, 749-766

\title{
신입사원의 심리적 계약 위반과 그의 변화
}

\author{
김 경 민 문 형 구 \\ 고려대학교 경영학과
}

본 연구는 신입사원이 조직의 약속, 즉 조직이 종업원에게 제공하기로 한 약속사항들을 어 느 수준으로 인지하는가에 따라 그들의 심리적 계약의 위배에 대한 인식이 달라진다는 가설 을 검증하고 있다. 연구를 위해 대기업 신입사원 222 명을 대상으로 3 개월의 시간차를 두고 두 번의 서베이를 실시하는 종단연구방식을 사용하였다. 분석 결과, 신입사원의 심리적 계약 위배에 대한 인지는 조직의 약속수준에 대한 인지와 정적인 관련성을 갖는 것으로 나타났 다. 즉, 조직이 종업원에게 제공하기로 한 약속의 수준이 변함에 따라 심리적 계약의 위배에 대한 인지 또한 함께 변하는 나타났다. 이와 함께, 신입사원이 초반에 인지한 조직의 약속 수준과 심리적 계약의 위배의 정도는 시간이 지남에 따라 줄어드는 양상을 나타냈다. 이러 한 결과는 신입사원이 심리적 계약의 위배를 인지하는 원인이 기존 사원과는 다를 수 있음 을 시사한다. 즉, 신입사원이 입사과정에서 조직이 종업원에게 제공할 혜택과 관련된 약속사 항을 비현실적으로 높게 인지함이 입사 후 초반에 강한 심리적 계약 위배를 경험하게 되는 주된 원인으로 작용할 수 있음을 의미한다. 이는 심리적 계약이 종업원의 주관적인 인지와 해석에 의존하는 지극히 개인화된 스키마로 구성되기 때문이며, 입사 과정에서 형성된 초기 의 심리적 계약은 상당부분 불완전하고 비현실적인 것으로서 실제 직무경험을 통해 지속적 인 완성의 과정을 거치는 것으로 해석할 수 있다. 따라서 조직은 신입사원의 위배경험을 줄 이기 위해 입사과정과 사회화 과정에 있어 보다 현실적인 수준의 커뮤니케이션을 시도할 필 요가 있으며, 실제 신입사원이 인지하고 있는 조직의 약속수준을 보다 명확히 파악하고 관 리할 필요가 있다.

주요어 : 심리적 계약의 위배, 신입사원, 센스메이킹, 조직의 약속 